\title{
Function, Innervation, and Neurotransmitter Signaling in Mice Lacking Type-II Taste Cells
}

\author{
AQ:au EEric D. Larson, ${ }^{1,2, *}$ Aurelie Vandenbeuch, ${ }^{1,2, *}$ Catherine B. Anderson,, ${ }^{1,2}$ and ${ }^{-S u e}$ C. Kinnamon ${ }^{1,2}$
}

https://doi.org/10.1523/ENEURO.0339-19.2020

${ }^{1}$ Department of Otolaryngology, University of Colorado Anschutz Medical Center, Aurora, CO 80045 and ${ }^{2}$ Rocky Mountain Taste and Smell Center, Aurora, CO 80045

\begin{abstract}
The Skn-1a transcription factor (Pou2f3) is required for Type II taste cell differentiation in taste buds. Taste buds in Skn-1a $a^{-/-}$mice lack Type II taste cells but have a concomitant expansion of Type III cells, providing an ideal model to determine the relative role of taste cell types in response specificity. We confirmed that chorda tympani responses to sweet, bitter, and umami stimuli were greatly reduced in the knock-outs (KOs) compared with wild-type (WT) littermates. $\mathrm{Skn}-1 \mathrm{a}^{-/-}$mice also had reductions to $\mathrm{NaCl}$ that were partially amilorideinsensitive, suggesting that both Type II and Type III cells contribute to amiloride-insensitive salt detection in anterior tongue. We also confirmed that responses to sour stimuli are equivalent in the KOs, despite the large increase in the number of Type III taste cells. To examine their innervation, we crossed the Htr3a-GFP (5$\mathrm{HT}_{3 \mathrm{~A}}$-GFP) reporter mouse with the $S \mathrm{kn}-1 \mathrm{a}^{-/-}$mice and examined geniculate ganglion neurons for GFP expression and responses to $5-\mathrm{HT}$. We found no change in the number of $5-\mathrm{HT}_{3 \mathrm{~A}}$-expressing neurons with $\mathrm{KO}$ of Skn-1a. Calcium imaging showed that only $5-\mathrm{HT}_{3 \mathrm{~A}}$-expressing neurons respond to exogenous $5-\mathrm{HT}$, while most neurons respond to ATP, similar to WT mice. Interestingly, despite loss of all Type II cells, the P2X3 antagonist AF353 blocked all chorda tympani responses. These data collectively raise questions pertaining the source of ATP signaling in the absence of Type II taste cells and whether the additional Type III cells are innervated by fibers that would have normally innervated Type II cells.
\end{abstract}

Key words: ATP; innervation; Pou2f3; serotonin; Skn-1a; taste

\section{Significance Statement}

Despite numerous studies, the role of specific taste cell types in taste responsivity and their connectivity to gustatory nerves is incompletely understood. Here we show that in Skn-1a knock-out (KO) mice where only Type I and III cells exist within taste buds, the number of gustatory ganglion cells innervating Type III cells remains unchanged and these neurons exhibit normal responses to gustatory neurotransmitters. Further, we show that although ATP release from taste buds is undetectable in Skn-1a KO mice, ATP is still required to drive gustatory neural output via the chorda tympani nerve. The source of the required ATP is unclear and begs further study.

\section{Introduction}

Taste signals generated by the interaction of molecules with receptors located on taste cells are transmitted to gustatory neurons to elicit a sensation of taste. Taste buds comprise three elongate taste cell types that are defined by molecular features and physiological properties

Received August 23, 2019; accepted January 15, 2020; First published January 23, 2020.

The authors declare no competing financial interests. (for review, see Roper and Chaudhari, 2017). Type I cells are generally considered to have primarily a support role, similar to glial cells in the nervous system. Type II cells express the G-protein-coupled receptors and downstream effectors for bitter, sweet, and umami taste stimuli. These cells when stimulated release ATP via the large

Author contributions: E.D.L., A.V., C.B.A., and S.C.K. designed research; E.D.L., A.V., and C.B.A. performed research; E.D.L., A.V., and C.B.A. analyzed data; E.D.L., A.V., and S.C.K. wrote the paper. 
conductance CALHM1 channels to activate P2X receptors on gustatory afferent fibers (Taruno et al., 2013). Type III cells respond to acids (sour stimuli) via an apically-located proton channel (Bushman et al., 2015; Ye et al., 2016) and when stimulated, release 5-HT (Huang et al., 2011,2008 ) to activate the $5-\mathrm{HT}_{3 \mathrm{~A}}$ receptors on gustatory afferents (Larson et al., 2015). The cell bodies of these neurons form part of the geniculate ganglion (VIIth cranial nerve), petrosal ganglion (IXth cranial nerve) and nodose ganglion (Xth cranial nerve). While 5-HT contributes to only a portion of the nerve response to taste, ATP is required for transmission of all taste modalities, as purinergic receptor antagonism or knock-out (KO) eliminates all nerve response to taste (Finger et al., 2005; Vandenbeuch et al., 2015). However, the role of ATP in the taste response for non-Type II cell mediated modalities remains elusive as release of ATP has only been detected from Type II cells (Huang et al., 2007; Romanov et al., 2007; Murata et al., 2010).

The development of Type II taste cells requires the transcription factor Skn-1a (Pou2f3). Skn-1a is a transcription factor (POU domain gene) involved in the regulation of gene expression in epidermal keratinocytes (Andersen et al., 1997) and regulates the generation and differentiation of taste cells (Matsumoto et al., 2011). Mice lacking Skn-1a do not express Type II taste cells and show deficient chorda tympani and glossopharyngeal nerve responses to sweet, umami, and bitter stimuli, but interestingly, although the number of Type III cells is increased by approximately $30 \%$ in taste buds of Skn$1 a^{-/-}$mice, acid responses are similar to those observed in wild-type (WT) animals (Matsumoto et al., 2011). Recently, Maeda et al. (2017) showed that the absence of Type II taste cells and the overexpression of Type III taste cells in the $S k n-1 a^{-/-}$mice do not alter the number of nodose/petrosal ganglion cells that innervate Type III cells using retrograde transfer of wheat germ agglutinin (WGA). These results suggest that connections between taste cells and ganglion cells are not influenced by the type of cells expressed in the tongue but are predetermined. What is not clear, however, is whether the additional Type III cells in the Skn-1a ${ }^{-/-}$mice are innervated by ganglion neurons expressing the serotonin receptor $5-\mathrm{HT}_{3 \mathrm{~A}}$, as in WT mice (Stratford et al., 2017). Here, we have crossed the $S k_{n}-1 a^{-/-}$animals with mice expressing

This work was supported by the National Institute on Deafness and Other Communication Disorders National Institutes of Health Grant R01 DC012555 (to S.C.K.).

${ }^{\star}$ E.D.L. and A.V. contributed equally to this work.

Acknowledgements: We thank Dr. Ichiro Matsumoto (Monell Chemical Senses Center) for providing the Skn-1 $\mathrm{a}^{-/-}$mice and reviewing the manuscript, Mei Li (University of Colorado Anschutz Medical Campus) for assistance with immunohistochemistry, and Dr. Thomas Finger (University of Colorado Anschutz Medical Campus) for helpful discussions.

Correspondence should be addressed to Eric D. Larson at eric.larson@ cuanschutz.edu.

https://doi.org/10.1523/ENEURO.0339-19.2020

Copyright (C) 2020 Larson et al.

This is an open-access article distributed under the terms of the Creative Commons Attribution 4.0 International license, which permits unrestricted use, distribution and reproduction in any medium provided that the original work is properly attributed.
GFP from the Htr3a promoter and examined the progeny for $5-\mathrm{HT}_{3 \mathrm{~A}}$ expression and function in the geniculate ganglion. Further, we examined the dependence of taste signaling on ATP in the Skn-1a ${ }^{-/-}$mice that lack Type II taste cells.

\section{Materials and Methods}

\section{Animals}

Experiments were performed on Skn-1a ${ }^{-/-}$and WT mice obtained from Ichiro Matsumoto at Monell Chemical Senses Center. Mice were crossed for several generation with C57BI/6. 5HT3A-GFP mice were purchased from MMRRC

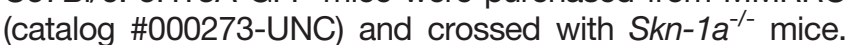
Both males and females aged between four and six months were used. Mice were housed at the author's institution in ventilated cages with access to water and food ad libitum. All experimental procedures were conducted in accordance with the Animal Care and Use Committee at the University of Colorado Anschutz Medical Center.

\section{RT-PCR}

Separate pools of circumvallate and fungiform taste tissues were isolated from three $S k n-1 a^{-/-}$and WT littermates. RNA was extracted in a QIAcube according to manufacturer's instructions using reagents from QIAGEN. A 30min DNase I treatment at room temperature to remove genomic DNA was included. Reverse transcription was performed using the QuantiTect Reverse Transcription kit which included an additional step for removal of genomic DNA. Two microliters of cDNA were added to the PCR reaction (Taq PCR Core). PCR conditions included an initial 5 min denaturation step followed by 40 cycles of 30 -s denaturation at $95^{\circ} \mathrm{C}, 30$-s annealing at $60^{\circ} \mathrm{C}$ and 45 -s extension at $72^{\circ} \mathrm{C}$ and a final 7 -min extension step. PCR primer sequences can be found in Table 1. We included fungiform cDNA from WT mice as a positive control and a no template negative control where water was added in place of cDNA. Amplified sequences were visualized by gel electrophoresis in $2 \%$ agarose gels stained with GelRed (Biotium).

\section{Taste bud immunohistochemistry}

Intraperitoneal injections of 5-hydroxy-L-tryptophan (5HTP; $50 \mathrm{mg} / \mathrm{kg}$; Sigma Aldrich) were performed on animals to increase 5-HT levels. After $1 \mathrm{~h}$, mice were deeply anesthetized with urethane and transcardially perfused using $4 \%$ paraformaldehyde. For lingual tissues, after $4 \mathrm{~h}$ postfix and cryoprotection in $20 \%$ sucrose overnight, 12 to $16-\mu \mathrm{m}$ cryostat sections were cut and mounted onto slides. After buffer washes with PBS, specific primary antibodies for each cell type were applied to the sections and immunoreacted overnight at $4^{\circ} \mathrm{C}$. Secondary antibodies were reacted for $2 \mathrm{~h}$ at room temperature and mounted with Fluoromount (Southern Biotech). Z-stack images were collected on a Leica SP5 or SP8 confocal microscope. Antibodies and their sources are listed in Table 2. 
Table 1. PCR primers

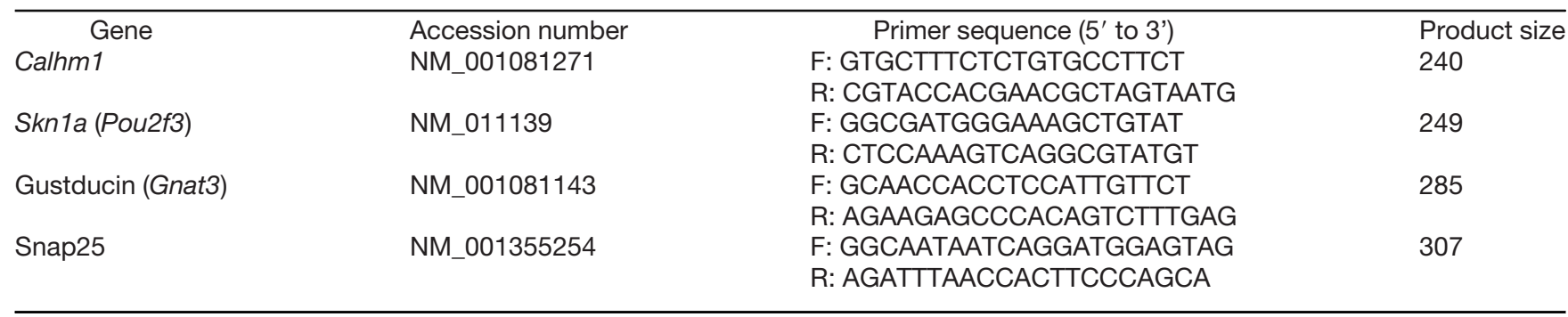

\section{Geniculate ganglion immunohistochemistry}

For geniculate ganglion imaging, geniculate ganglia were removed from paraformaldehyde-perfused heads and postfixed for $1 \mathrm{~h}$. Ganglia were optically cleared with PACT (Cronan et al., 2015) and labeled with primary antibodies against GFP, P2X3, and SNAP25 and imaged on a Leica SP8 confocal microscope.

\section{Geniculate ganglion image quantification}

Cleared whole mount ganglia were imaged in a single field of view with $1 \mu \mathrm{m}$ axial spacing. Maximal z-projections of $10-\mu \mathrm{m}$ substacks were created with ImageJ. Regions of interest (ROIs) were drawn around individual cells as identified by SNAP25 and DAPI and the average fluorescence value of each channel was measured for each ROI. Fluorescence intensity values were background subtracted and normalized for each image. Cells were scored as positive or negative for each channel using a threshold intensity value (Larson et al., 2015). Thresholds for each channel were determined by fitting intensity value histograms with Gaussian functions (two peak if bimodal). For bimodal distributions, threshold was determined by any value $>2$ SD above the median of the lower peak.

\section{Taste receptor cell quantification}

Type III cells were counted from images of lingual slices labeled with antibodies against SNAP25. We chose SNAP25 to identify Type III cells as it has been previously shown as the broadest marker of Type III cells in the anterior tongue (Wilson et al., 2017). From each three-dimensional image collected, a plane from the middle, upper, and lower quadrants was extracted, and cell profiles with a clear nuclear region were counted per taste bud. This method minimized counting cells that persisted through multiple optical sections. Counts were parsed and plotted using a custom "R" script. Count data were analyzed using a Kruskal-Wallis test followed by Dunn test for multiple comparisons in $\mathrm{R}$ with the dunn.test and FSA packages (Dinno, 2017; Ogle et al., 2019).

\section{Taste bud innervation quantification}

Image stacks of different taste fields were analyzed using ImageJ. Stacks were processed using "Subtract Background" (rolling ball radius $50 \mathrm{px}$ ), "Median" (radius 2), and "Auto Threshold" (Otsu method, stack histogram) to create multichannel binary images. ROls were drawn around individual taste buds and the area, mean fluorescence, integrated density, and voxel size/volume were measured for each optical section. Using a custom $\mathrm{R}$ script, the total analyzed volume and the total labeled volume were calculated for each ROI. Innervation density was plotted as labeled volume/total volume.

\section{5-HT ${ }_{3 A}$-GFP, P2X3 nerve fiber quantification}

Lingual sections were labeled with antibodies against GFP and P2X3. High-resolution 3D images were acquired on a Leica SP8 of all taste fields. Images were subject to a custom analysis pipeline to quantify the proportion of P2X3 immunoreactivity that overlapped with GFP immunoreactivity. In ImageJ, ROIs pertaining to individual taste buds were extracted and saved as new images for further processing which included Subtract Background (rolling ball radius $50 \mathrm{px}$ ), Median (radius 2), and Auto Threshold (Otsu method, stack histogram) to create multichannel binary images. Images and image metadata were imported to $\mathrm{R}$ using raster, rgdal, and $s p$ packages (Pebesma and Bivand, 2005; Bivand et al., 2013, 2019; Hijmans, 2019). A custom script was used to calculate the volume of each taste bud ROI that was occupied by

Table 2. List of primary and secondary antisera

\begin{tabular}{|c|c|c|c|c|}
\hline Antiserum & Company & Catalog number & Dilution & RRID \\
\hline Chicken polyclonal anti-GFP & Aves Lab & GFP-1020 & $1: 2000$ & AB_10000240 \\
\hline Goat polyclonal anti- GNAT3 & Aviva Systems Bio & NC9510598 & $1: 500$ & AB_10882823 \\
\hline Goat polyclonal anti-SNAP25 & Genetex & GTX89577 & $1: 200$ & AB_10724125 \\
\hline Donkey anti-chicken 488 & Jackson ImmunoResearch & $703-546-155$ & $1: 1000$ & AB_2340375 \\
\hline Donkey anti-rabbit 568 & Invitrogen & A10042 & $1: 1000$ & AB_2534017 \\
\hline
\end{tabular}


a P2X3+ and/or GFP+ voxel. Data are displayed as GFP:P2X3+ volume divided by $\mathrm{P} 2 \mathrm{X} 3+$ volume using ggplot2. Statistical comparison was performed using a nonparametric Kruskal-Wallis test followed by Dunn test for multiple comparisons.

\section{Calcium imaging}

Calcium imaging of isolated geniculate ganglion neurons was performed as previously described (Larson et al., 2015). Briefly, geniculate ganglia were extracted from euthanized animals, washed briefly in minimum essential medium with Earle's balanced salts (MEM/EBSS; HyClone) and placed in MEM/EBSS supplemented with $1.25 \mathrm{mg} / \mathrm{ml}$ trypsin (Sigma-Aldrich) and $2.5 \mathrm{mg} / \mathrm{ml}$ collagenase A (Roche Diagnostics) for $30 \mathrm{~min}$. Ganglia were washed with MEM/EBSS, gently triturated with a fire-polished glass pipette, and resuspended in HEPES buffer (136 mM NaCl, $5.6 \mathrm{mM} \mathrm{KCl}, 1 \mathrm{mM} \mathrm{MgCl}_{2}$, $2.2 \mathrm{mM} \mathrm{CaCl}_{2}$, $11 \mathrm{mM}$ glucose, and $10 \mathrm{mM}$ HEPES; $\mathrm{pH}$ 7.4). Cells were plated on poly-D-lysine $(0.02 \mathrm{mg} / \mathrm{ml})$ coated coverslips before loading with $2 \mu \mathrm{M}$ fura-2 AM (Invitrogen) with $0.01 \%$ Pluronic F-127 (Invitrogen). Cells were continually perfused with HEPES buffer or HEPES buffer plus $10 \mu \mathrm{M}$ ATP, $10 \mu \mathrm{M} 5-\mathrm{HT}$, or HEPES buffer with $55 \mathrm{mM} \mathrm{KCl}$. Cells were imaged using an inverted microscope equipped with a 40x oil immersion lens, Lamba 10-3 filter wheel (with 340 and 380 excitation filters; Sutter), and a QImaging Retiga R3 CCD camera. Acquisition was controlled using Imaging Workbench 6.1 (Indec Biosystems). Baseline emission ratio $\left(340_{\mathrm{ex}}\right.$ and $\left.380_{\mathrm{ex}}\right)$ values were determined as the first $10-15 \mathrm{~s}$ of recording and were subtracted from the peak ratio during stimulus perfusion. In the absence of a visible response, the value was taken $30 \mathrm{~s}$ after onset of stimulus perfusion. Data are plotted as baseline subtracted values divided by the peak values.

\section{Nerve recording}

$S k n-1 a^{-/-}$and WT littermates were anesthetized with an intraperitoneal injection of urethane $(2 \mathrm{mg} / \mathrm{kg}$; Sigma Aldrich) and placed in a head holder. The trachea was cannulated to facilitate breathing. Using a ventral approach, the chorda tympani was exposed, cut near the tympanic bulla and placed on a platinum-iridium wire. A reference electrode was placed in a nearby muscle. The signal was fed to an amplifier (P511; Grass Instruments), integrated and recorded using AcqKnowledge software (Biopac). The anterior part of the tongue containing the fungiform papillae was continuously stimulated with $\mathrm{NH}_{4} \mathrm{Cl} 100 \mathrm{mM}$, sucrose $500 \mathrm{mM}$, quinine $10 \mathrm{mM}$, MSG $100 \mathrm{mM}$, MSG $100 \mathrm{mM}+\mathrm{IMP} 0.5 \mathrm{mM}, \mathrm{HCl} 10 \mathrm{mM}$, citric acid $10 \mathrm{mM}, \mathrm{NaCl}(30,100$, and $300 \mathrm{mM})$. In some experiments, amiloride $(100 \mu \mathrm{M})$, an epithelial $\mathrm{Na}^{+}$channel $(\mathrm{ENaC})$ blocker was added to $\mathrm{NaCl}$. In some experiments, the P2X3 antagonist, AF353, was diluted in water (1 mM) and applied on the tongue for $10 \mathrm{~min}$. Each stimulus was applied for $30 \mathrm{~s}$ and rinsed with water for $40 \mathrm{~s}$. Since all responses could potentially be affected in the KO mice, each response was normalized to the baseline (Vandenbeuch et al., 2013, 2015; Larson et al., 2015).
Although we drew similar conclusions when data were normalized to $\mathrm{NH}_{4} \mathrm{Cl}$ responses (data not shown), we present data as baseline-normalized as the cell type involved in the $\mathrm{NH}_{4} \mathrm{Cl}$ response is likely to be Type III cells (Oka et al., 2013). To analyze the data, the baseline integrated response was averaged over $10 \mathrm{~s}$ prior to stimulation of each tastant and subtracted from the average amplitude of each integrated response (over $30 \mathrm{~s}$ ). The baseline subtracted responses were then divided by the respective baseline.

\section{ATP release}

An enzymatic cocktail containing Dispase II $(3 \mathrm{mg} / \mathrm{ml}$; Roche) and Elastase $(2.5 \mathrm{mg} / \mathrm{ml}$; Worthington) diluted in Tyrode's was injected under the circumvallate papillae. The epithelium was peeled after 20 min incubation in Tyrode's and placed on a modified Ussing chamber $(42 \mu \mathrm{l})$. The basolateral part of the papilla was bathed in Tyrode's while the apical part was stimulated with $5 \mu \mathrm{l}$ of artificial saliva, citric acid $(20 \mathrm{mM})$, or $\mathrm{NaCl}(500 \mathrm{mM})$ diluted in artificial saliva. Only one stimulus was applied on each preparation and could not be rinsed because of the high sensitivity to mechanical stimulation. The Tyrode's containing the releasate from taste buds was collected after each stimulation, transferred to a 96-well plate and placed in a plate reader (Synergy HT, Biotek). $42 \mu \mathrm{l}$ of luciferase (ATP bioluminescence kit HS II; Roche) was automatically injected into each well and the luminescence reading was performed. Known concentrations of ATP solutions were also read to obtain a standard ATP curve and convert relative light units into ATP concentrations (nM). The Tyrode's solution contained the following: 140 $\mathrm{mM} \mathrm{NaCl}, 5 \mathrm{mM} \mathrm{KCl}, 4 \mathrm{mM} \mathrm{CaCl} 2,1 \mathrm{mM} \mathrm{MgCl}_{2}, 10 \mathrm{mM}$ glucose, $1 \mathrm{mM}$ Na-Pyruvate, and $10 \mathrm{mM}$ HEPES, pH adjusted to 7.4 with $\mathrm{NaOH}$. Artificial saliva contained the following: $2 \mathrm{mM} \mathrm{NaCl}, 5 \mathrm{mM} \mathrm{KCl}, 3 \mathrm{mM} \mathrm{NaHCO}_{3}, 3 \mathrm{mM}$ $\mathrm{KHCO}_{3}, 1.8 \mathrm{mM} \mathrm{HCl}, 0.25 \mathrm{mM} \mathrm{CaCl}, 0.25 \mathrm{mM} \mathrm{MgCl}_{2}$, $0.12 \mathrm{mM} \mathrm{K}_{2} \mathrm{HPO}_{4}$, and $0.12 \mathrm{mM} \mathrm{KH}_{2} \mathrm{PO}_{4}$.

\section{Statistics}

All statistical calculations were performed in Sigmaplot (V12.5, Systat Software, SCR_003210). Statistical tests within each figure are described in Table 3; $p<0.05$ was considered significant.

\section{Results}

\section{Skn-1a ${ }^{-/-}$mice do not express canonical Type II taste cell markers}

RT-PCR confirmed that fungiform and circumvallate taste buds of $S k n-1 a^{-/-}$mice do not express Pou2f3 (Skn1a) or the Type II cell marker (Gnat3), however all taste buds expressed the Type III cell marker Snap25 (Fig. 1). $S k n-1 a^{-1-}$ mice do not express the ATP release channel Calhm1. We also used immunohistochemistry to confirm that no Type II cell markers were present in Skn-1a ${ }^{-/-}$ mice. As shown in Figure 2, neither GNAT3 nor PLC $\beta 2$ immunoreactivity was observed in $S k n-1 a^{-/-}$mice. However, the number of Type III cells labeled with 5-HT and SNAP25 is increased in Skn-1a $a^{-/-}$compared with WT 
Table 3. Statistical table

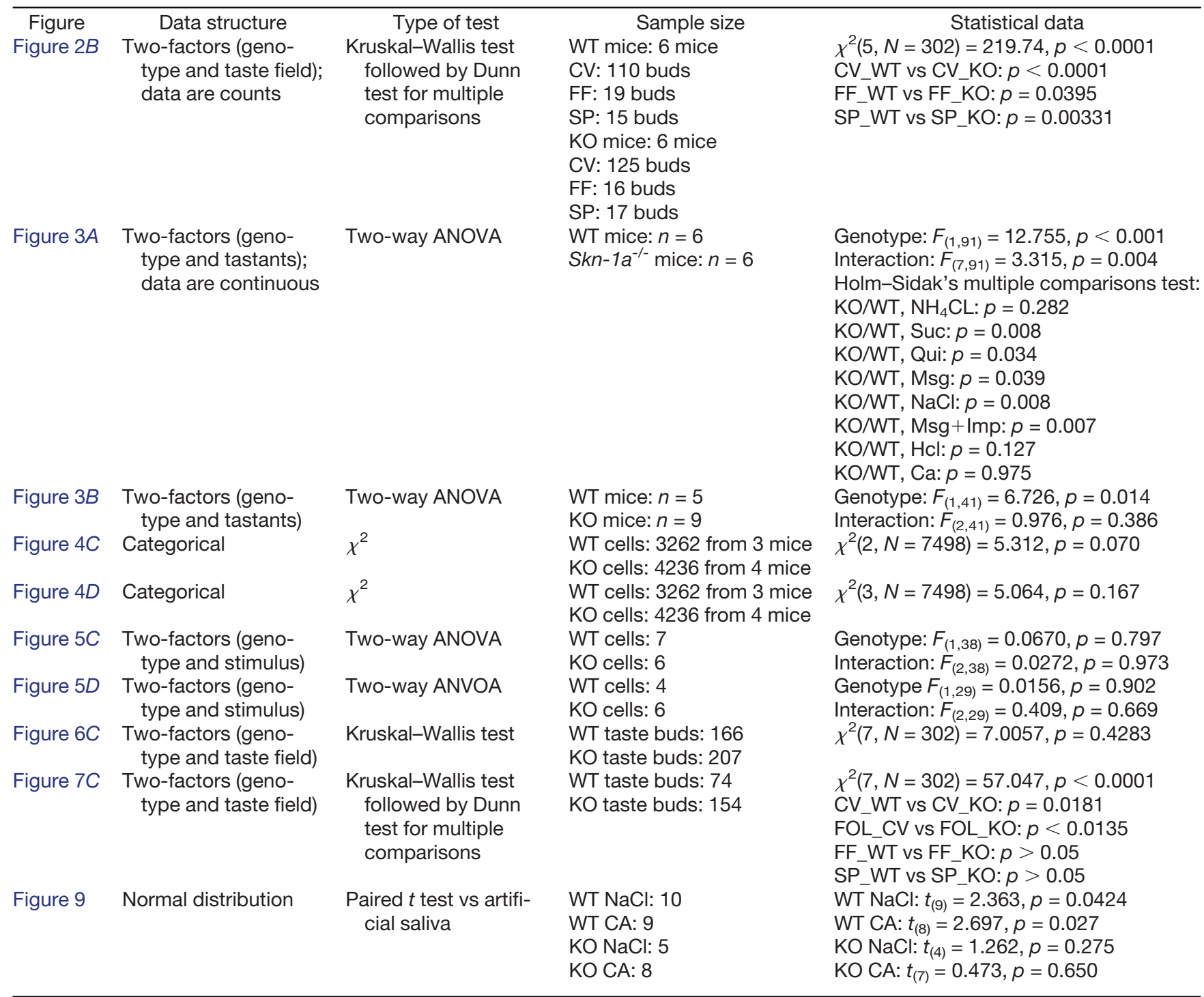

as observed previously in Matsumoto et al. (2011). Cell counting of SNAP25 immunoreactive cell profiles confirms previous reports that the number of Type III cells is increased in CV taste buds. Additionally, we show that there is a significant, commensurate increase in Type III cells in the anterior taste fields as well (Fig. 2B). In mice pre-injected with the 5-HT precursor 5-HTP, the majority of Type III cells in Skn-1a ${ }^{-/-}$mice were immunoreactive for 5-HT (data not shown).

\section{Skn-1a/-- mice have diminished taste responses conveyed by Type II cells}

Chorda tympani responses to various tastants were compared between Skn-1a ${ }^{-/-}$and WT (Fig. 3A). While responses to acids (citric acid and $\mathrm{HCl}$ ) and $\mathrm{NH}_{4} \mathrm{Cl}$ were similar in both genotypes, responses to bitter (quinine), sweet (sucrose), umami (MSG with or without IMP), and salty $(\mathrm{NaCl})$ stimuli were significantly decreased. $\mathrm{NaCl}$ responses were significantly decreased indicating that salt taste is also partially conveyed by Type II taste cells. When amiloride was added to $\mathrm{NaCl}$ at different concentrations, responses were diminished in the $S k_{n} 1 \mathrm{a}^{-/-}$mice but not abolished suggesting that Type III cells participate in the transduction of the amiloride-insensitive salt response (Fig. 3B).

\section{Skn-1a-/- mice have the same number of $5-\mathrm{HT}_{3 \mathrm{~A}^{-}}$ expressing geniculate ganglion neurons as the WT littermates}

Maeda et al. (2017) showed, via retrograde transfer of WGA from Type III cells, that the total number of nodose/ petrosal ganglion neurons that innervate Type III cells remains unchanged in $S k n-1 a^{-/-}$mice, despite the increased number of Type III cells. All gustatory neurons express the $\mathrm{P} 2 \mathrm{X}$-family purinergic receptors and a subset expresses $5-\mathrm{HT}_{3}$ receptors which preferentially contacts Type III cells (Larson et al., 2015; Stratford et al., 2017). We tested the hypothesis that additional geniculate ganglia express 

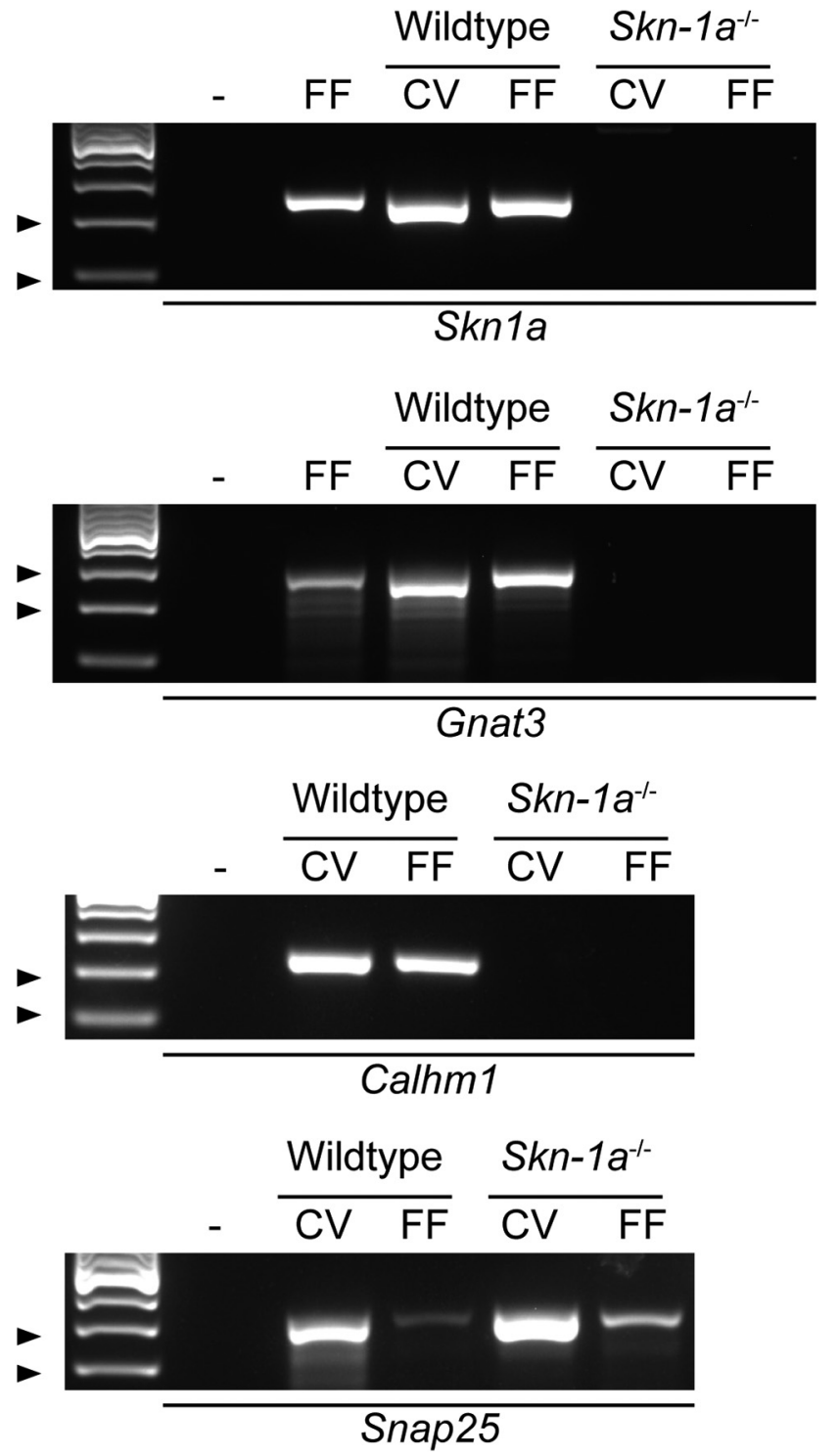

Figure 1. RT-PCR confirms lack of Type II cell markers. RNA was extracted from fungiform and circumvallate taste buds of WT and $\mathrm{Skn}-1 \mathrm{a}^{-/-}$mice. After reverse transcription, cDNA was interrogated for the presence of Skn1a, Gnat3, Calhm1, and Snap25. Arrowheads denote ladder bands: Skn1a, 200 and 100 bp; Gnat3, 300 and $200 \mathrm{bp}$; Calhm1, 200 and $100 \mathrm{bp}$; Snap25, 300 and $200 \mathrm{bp}$. Data are representative of RNA extracted from three mice of each genotype; - is no template negative control, FF lanes in Skn1a and Gnat3 gel are RNA from C57bl/6j fungiform taste buds.

5- $\mathrm{HT}_{3}$ receptors to compensate for the additional Type III cells in $S k n-1 a^{-/-}$mice, and that this change would be reflected when the 5- $\mathrm{HT}_{3 \mathrm{~A}}$-GFP reporter mouse is crossed with $S k n-1 a^{-/-}$mice. We showed that the total number of geniculate ganglion neurons expressing SNAP25, P2X3, or 5-HT3A was not significantly different between genotype (Fig. 4C). Additionally, we showed that the number of geniculate ganglion neurons expressing both P2X3 (gustatory neuron marker; Bo et al., 1999; Ishida et al., 2009; Dvoryanchikov et al., 2017) and $5-\mathrm{HT}_{3 A^{-}}$-driven GFP is similar to the number in WT littermates (Fig. 4D).
Skn-1a ${ }^{-/-}$mice show normal calcium response to ATP and 5-HT in geniculate ganglion neurons

We next isolated geniculate ganglion neurons from Skn-1a ${ }^{-/-}$mice crossed with $5-\mathrm{HT}_{3 \mathrm{~A}}$-GFP mice and examined response profiles to ATP and 5-HT. We observed similar response profiles in both $\mathrm{KO}$ and WT neurons. That is, GFP-expressing ganglion neurons responded to exogenous 5-HT and ATP while GFP-negative neurons responded only to ATP, similar to observations in WT neurons (Fig. $5 C, D$ ). Thus, in agreement with Maeda et al. (2017) we conclude that there is no change at the level of the geniculate ganglion to compensate for the increased number of Type III taste cells in Skn-1a ${ }^{-/-}$mice. 5-HT signaling is not upregulated in $S k n-1 a^{-/-}$mice.

\section{Skn-1 $\mathbf{a}^{-/-}$mice show normal innervation of taste buds}

To determine if the taste buds of $S k n-1 a^{-/-}$mice have similar numbers of nerve fibers compared with WT, we used an antibody against P2X3, since all gustatory nerve fibers express P2X3 (Bo et al., 1999; Ishida et al., 2009; Dvoryanchikov et al., 2017). The density of P2X3-labeled gustatory nerve fibers was compared in taste fields of $\mathrm{KO}$ and WT animals (Fig. 6). Total innervation density was calculated as percent labeled voxels divided by total number of voxels per imaged taste bud. No appreciable differences were observed between KO and WT in any taste field examined.

\section{5-HT $3 \mathrm{~A}_{3}$-GFP innervation of taste buds in Skn-1a ${ }^{-/-}$ mice}

We have now shown that the overall level of P2X3+ innervation is unchanged and the overall number of $5-\mathrm{HT}_{3 \mathrm{~A}^{-}}$ GFP (Type III cell innervating) ganglion cells remains unchanged in $S k n-1 a^{-/-}$mice. This raises the possibility that the increased Type III cells in $S k n-1 a^{-/-}$mice are innervated by either (1) non 5- $\mathrm{HT}_{3 \mathrm{~A}}$ neurons, (2) increased branches of $5-\mathrm{HT}_{3 \mathrm{~A}}$ neurons, or (3) no neurons at all. The most former seems unlikely, as if the new Type III taste cells were innervated by a new population of neurons, we would have expected to see increased chorda tympani responses to sour and salty as more fibers would be activated. In fact, we observed decreased salty responses and unchanged sour responses in $S k n-1 a^{-/-}$mice. Thus, a more plausible explanation is that either the "new" Type III cells of $S k n-1 a^{-/-}$mice are not innervated or are innervated by increased branching of neurons. To address this, we imaged taste buds of Skn-1a ${ }^{-/-}$mice (and WT littermates) crossed with 5- $\mathrm{HT}_{3 \mathrm{~A}}$-GFP mice. Quantitative analysis of these images showed a subtle increase in the proportion of P2X3-immunoreactive fibers that were also $5-\mathrm{HT}_{3 A^{-}}$ GFP + when Skn-1a was KO. While significance was only achieved in more posterior taste fields, a positive trend was observed in the anterior fields (Fig. 7).

\section{Skn-1a ${ }^{-/-}$mice require ATP to transmit gustatory neural responses}

ATP is required for the transmission of all taste qualities (Finger et al., 2005; Vandenbeuch et al., 2015) and the P2X3 antagonist AF353 blocks all taste responses 

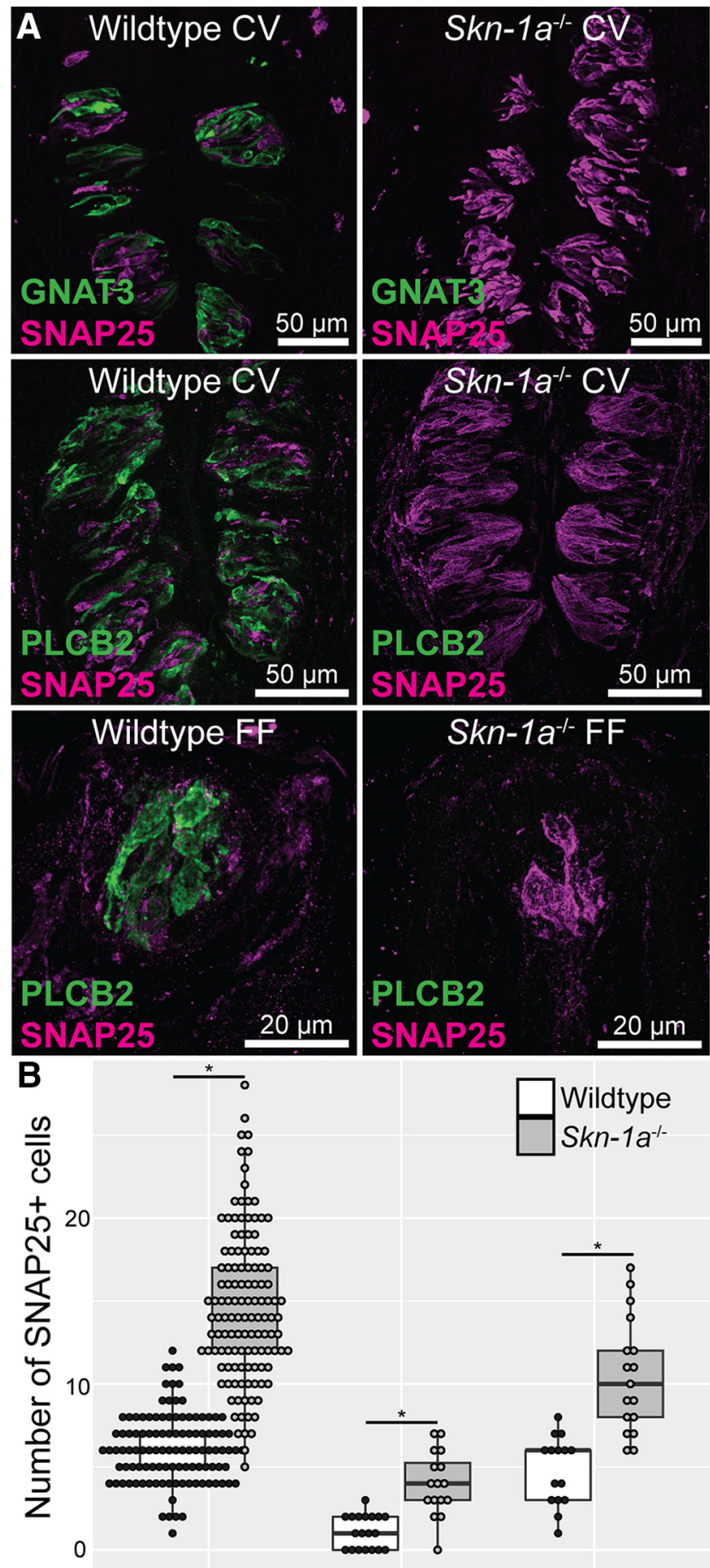

$\mathrm{CV}$

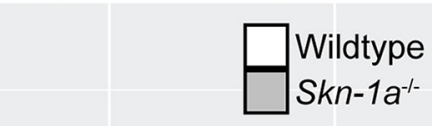

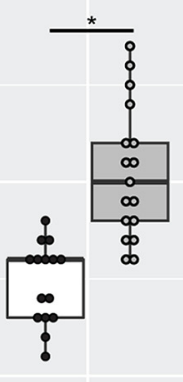

$\mathrm{SP}$

Figure 2. IHC confirms lack of GNAT3- and PLC $\beta 2$-expressing Type II cells in Skn-1a ${ }^{-/-}$mice. A, Lingual sections from Skn$1 a^{-/-}$and WT littermates were labeled with antibodies against SNAP25 (magenta) and GNAT3 (green) or PLC $\beta 2$ (green). In $S k n-1 a^{-/-}$, there was no detectable levels of Type II cell markers GNAT3 or PLC $\beta 2$. B, Semi-quantitative IHC reveals increased numbers of Type III cells in circumvallate, fungiform, and soft palate taste buds. Each dot represents a single taste bud. Box plots are summaries of all datapoints. Acquisition settings were equalized between WT and KO for all channels. Images are maximal $z$-projections of 12 - to $16-\mu \mathrm{m}$ image stacks. $\mathrm{CV}=$

(Vandenbeuch et al., 2015). When applying AF353 for $10 \mathrm{~min}$ on the anterior part of $S k n-1 a^{-/-}$tongues, chorda tympani responses to all taste stimuli were totally abolished (Fig. 8). These results suggest that ATP is required to transmit the signal from taste cells to nerve fibers.

\section{Skn-1a $\mathrm{a}^{-/-}$mice do not release ATP to any tastants}

To clarify the source of ATP required for the taste signal transmission in $S k n-1 a^{-/-}$mice, the amount of ATP released to different tastants was measured. Using a luciferase assay, no ATP was released from taste buds of the $S k n-1 a^{-1-}$ mice following $\mathrm{NaCl}$ or citric acid stimulation. Conversely, ATP was released in the WT animals in response to the same stimuli (Fig. 9). Although we cannot rule out the possibility that the technique used was not sensitive enough, it seems unlikely that the source of ATP required for transmission comes from Type III cells in the Skn-1a $a^{-/-}$mice.

\section{Discussion}

In this manuscript we confirm earlier studies showing that the transcription factor Skn-1a is required for generation of Type II taste cells (Matsumoto et al., 2011) and that the resulting expansion of Type III cells in the Skn-1a ${ }^{-/-}$ mice does not alter the number of innervating gustatory neurons (Maeda et al., 2017). Here, we extend these earlier studies to show that despite the large increase in the number of serotonergic Type III taste cells in the Skn-1a ${ }^{-/-}$ mice, the ratio of geniculate ganglion neurons expressing the serotoninergic target receptor $5-\mathrm{HT}_{3 \mathrm{~A}}$ is unchanged with respect to WT mice. Further, we show that $S k n-1 a^{-/-}$ mice still require ATP for the transmission of sour and salty tastes to the nervous system despite the absence of Type II taste cells, which are the only taste cells known to release ATP.

We first confirmed using RT-PCR that the transcription factor Skn-1a, the G-protein Gnat3, and ATP release channel Calhm 1 are indeed missing in the $S k n-1 a^{-/-}$mice. In addition, we confirmed that the Type III cell marker Snap25 is present in both WT and KO mice, ensuring the integrity of the mRNA in the KO mice. We then used immunohistochemistry to show that the $S k n-1 a^{-/-}$mice lack expression of the canonical Type II taste cell marker PLC $\beta 2$ and that SNAP25 expressing Type III taste cells were expanded in both anterior and posterior taste fields to compensate for the loss of Type II taste cells. We also confirmed, using chorda tympani nerve recording of Skn$1 a^{-/-}$mice, that responses to stimuli normally transduced by Type II cells, i.e., bitter, sweet, and umami, were largely missing in the KOs compared with WT littermates. Also, in agreement with Matsumoto et al. (2011), we showed that responses to sour (acidic) stimuli were similar in $\mathrm{KO}$ and control mice, despite the large expansion of Type III cells. However, Matsumoto et al. (2011) showed a non-statistically significant decrease to $\mathrm{NaCl}$, while we found

continued

circumvallate, FF = fungiform; $* p<0.05$ by Kruskal-Wallis test followed by Dunn test for multiple comparisons. 


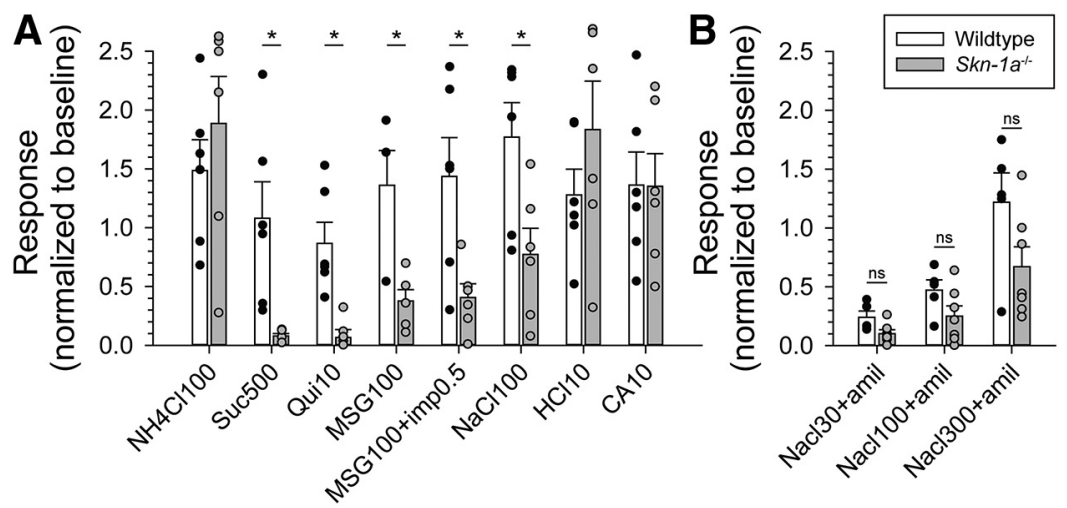

Figure 3. Skn-1a $\mathrm{a}^{-/-}$mice have suppressed responses to Type II-mediated taste modalities. $\boldsymbol{A}$, Chorda tympani nerve activity of Skn$1 \mathrm{a}^{-/-}$and WT littermates was monitored in response to lingually applied taste solutions (100 $\mathrm{mM} \mathrm{NH}_{4} \mathrm{Cl}, 500 \mathrm{mM}$ sucrose, $10 \mathrm{mM}$ quinine- $\mathrm{HCl}, 100 \mathrm{mM}$ mono-sodium glutamate, $100 \mathrm{mM}$ mono-sodium glutamate plus $0.5 \mathrm{mM}$ inosine monophosphate, $100 \mathrm{mM}$ $\mathrm{NaCl}, 10 \mathrm{mM} \mathrm{HCl}$, and $10 \mathrm{mM}$ citric acid). Integrated nerve activity over $30 \mathrm{~s}$ of stimulation was normalized to baseline; $N=6$ mice

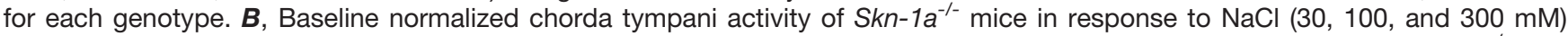
with pre- and concurrent application of $100 \mu \mathrm{M}$ amiloride. No significant differences were detected between WT and Skn-1a ${ }^{-/-}$. Bar charts indicate sample mean, error bars represent SEM, and superimposed dot plot represents each individual animal. ns $=$ no significance; $* p<0.05$ by two-way repeated measures ANOVA with Holm-Sidak post hoc test.
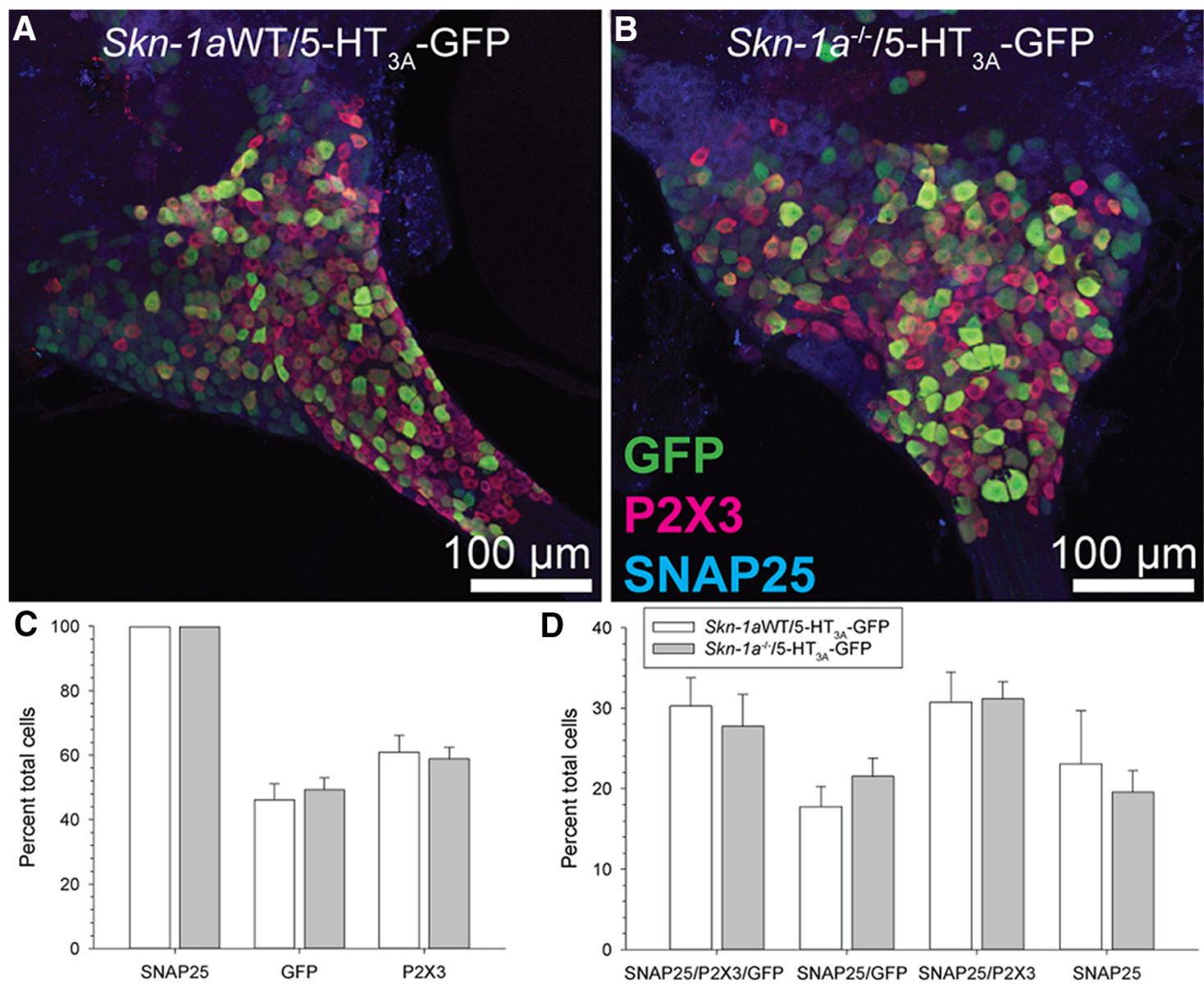

Figure 4. No change in the number of $5-\mathrm{HT}_{3 A}-\mathrm{GFP}$ geniculate ganglion neurons in $S k n-1 a^{-/-}$mice. Skn-1a ${ }^{-/-}$mice were crossed to 5- $\mathrm{HT}_{3 \mathrm{~A}}$-GFP mice. $\boldsymbol{A}, \boldsymbol{B}$, Geniculate ganglia of $\mathrm{Skn}-1 \mathrm{a}^{-/-} / 5-\mathrm{HT}_{3 \mathrm{~A}}-\mathrm{GFP}$ and WT littermates (still expressing 5-HT $3 \mathrm{~A}^{-\mathrm{GFP}}$ ) were labeled with antibodies against GFP (green), P2X3 (magenta), and SNAP25 (blue). The number of labeled cells was counted for each label. $\boldsymbol{C}$, Percent of total cells showing GFP, P2X3, or SNAP25 immunoreactivity. KO of Skn-1a had no effect. $\boldsymbol{D}$, Percent of total cells showing each combination of labels. KO of Skn-1a had no effect. Data are a summary of from three WT and four KO mice. Bar chart depicts sample mean and error bars show SEM. 

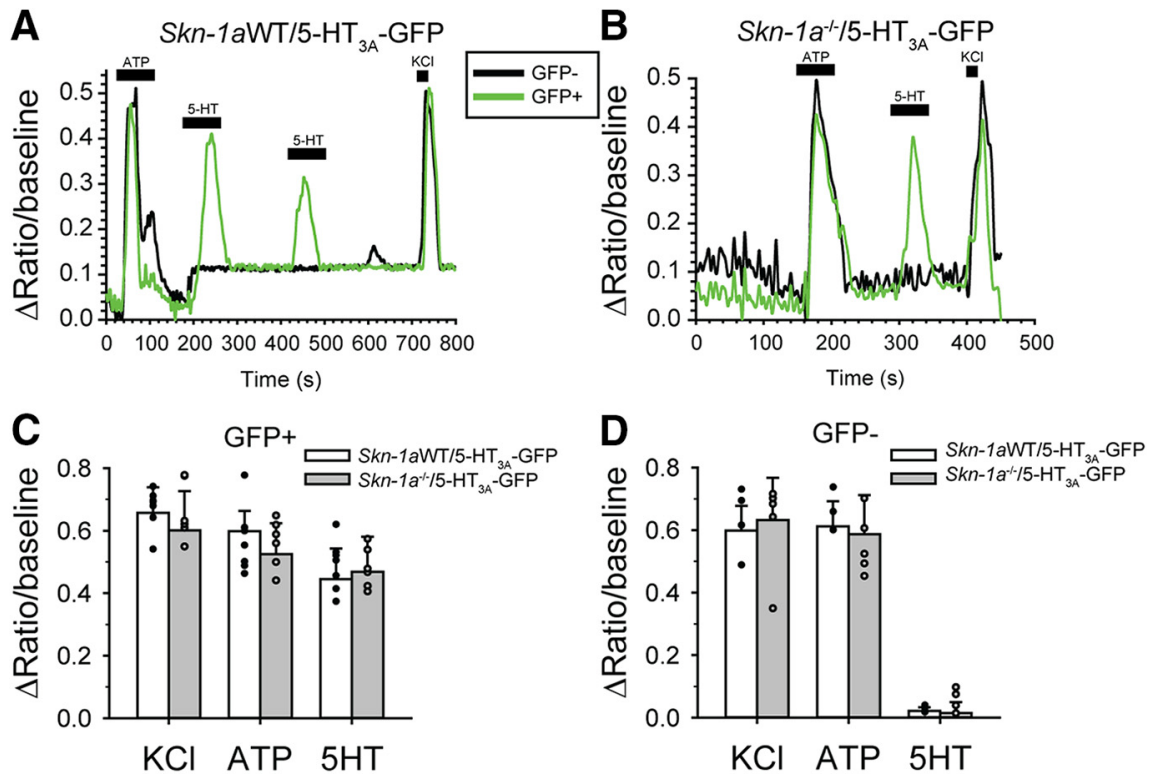

Figure 5. KO of Skn-1a does not affect responsiveness of geniculate ganglion neurons to ATP or 5-HT. Skn-1a ${ }^{-/-}$mice were crossed to $5-\mathrm{HT}_{3 \mathrm{~A}}$-GFP mice. $\boldsymbol{A}, \boldsymbol{B}$, Raw calcium imaging traces of isolated, individual GFP+ (green) or GFP- (black) geniculate ganglion neurons in response to $10 \mu \mathrm{M}$ ATP, $10 \mu \mathrm{M} 5-\mathrm{HT}$, or $55 \mathrm{mM} \mathrm{KCl}$. $\boldsymbol{C}, \boldsymbol{D}$, Summary of responses to exogenous stimuli; $N=7$ GFP,+ 4 GFP- from 3 Skn-1a $a^{-/} / 5-\mathrm{HT}_{3 A}-\mathrm{GFP}$, and $6 \mathrm{GFP}+$ and 6 GFP- from $3 \mathrm{Skn}-1 \mathrm{aWT} / 5-\mathrm{HT}_{3 \mathrm{~A}}-\mathrm{GFP}$. Bar charts indicate sample mean, error bars represent SEM, and superimposed dot plot represents each individual cell; $* p<0.05$ by Two-way ANOVA with HolmSidak post hoc test.
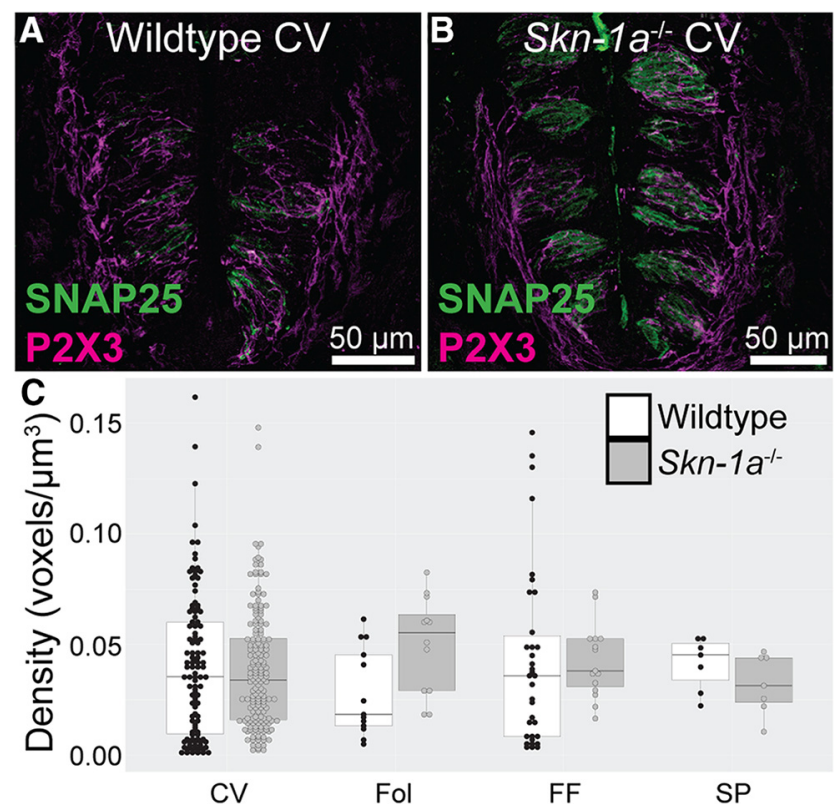

Figure 6. No change in the innervation density of taste buds in $S k n-1 a^{-/-}$mice. $\boldsymbol{A}, \boldsymbol{B}$, Lingual slices of $S k n-1 a^{-/-}$and WT littermates were labeled with antibodies against SNAP25 and P2X3. C. P2X3 immunoreactivity density was calculated for each taste bud. Dots represent individual taste buds and the box plot demonstrates distribution of data. CV, circumvallate; Fol, foliate; FF, fungiform; SP, soft palate. Data are from six WT and five Skn$1 a^{-\gamma-}$ mice. No significant interactions were found by KruskalWallis test. responses to $\mathrm{NaCl}$ were significantly reduced, although not eliminated in the KOs, and that other sodium containing stimuli (e.g., MSG) showed small residual responses in the KO. We hypothesize that this difference is mainly due to experimental conditions: we used urethane anesthesia and baseline normalization while Matsumoto et al. (2011) used pentobarbital plus urethane anesthesia and $\mathrm{NH}_{4} \mathrm{Cl}$ normalization. Larson et al. (2015) have shown that sodium pentobarbital interferes with accurate measurement of $\mathrm{NaCl}$ responses. Our data suggest that Type II cells transduce a portion of the responses to $\mathrm{NaCl}$, as others have suggested, although this point is still debated (Oka et al., 2013; Lewandowski et al., 2016; Roebber et al., 2019). Two distinct mechanisms are responsible for transduction of $\mathrm{NaCl}$, an amiloride-sensitive mechanism, mediated by the epithelial $\mathrm{Na}$ channel $\mathrm{ENaC}$ and limited to anterior tongue (Kretz et al., 1999; Chandrashekar et al., 2010), and an unidentified amiloride-insensitive mechanism, found in all taste fields. Our results show that the addition of amiloride to $\mathrm{NaCl}$ does not completely abolish the salt response in the $S k n-1 a^{-/-}$mice suggesting that a portion of the amiloride-insensitive response is conveyed by Type III cells. Both Type II and Type III cells were previously thought to be responsible for amiloride-insensitive salt taste (Oka et al., 2013; Lewandowski et al., 2016). However, a recent study using Pirt-GCamp6 mice showed $\mathrm{NaCl}$ responses in fungiform taste buds were present only in Type II taste cells, and that these responses were entirely amiloride-insensitive (Roebber et al., 2019). These latter data are inconsistent with our data, 

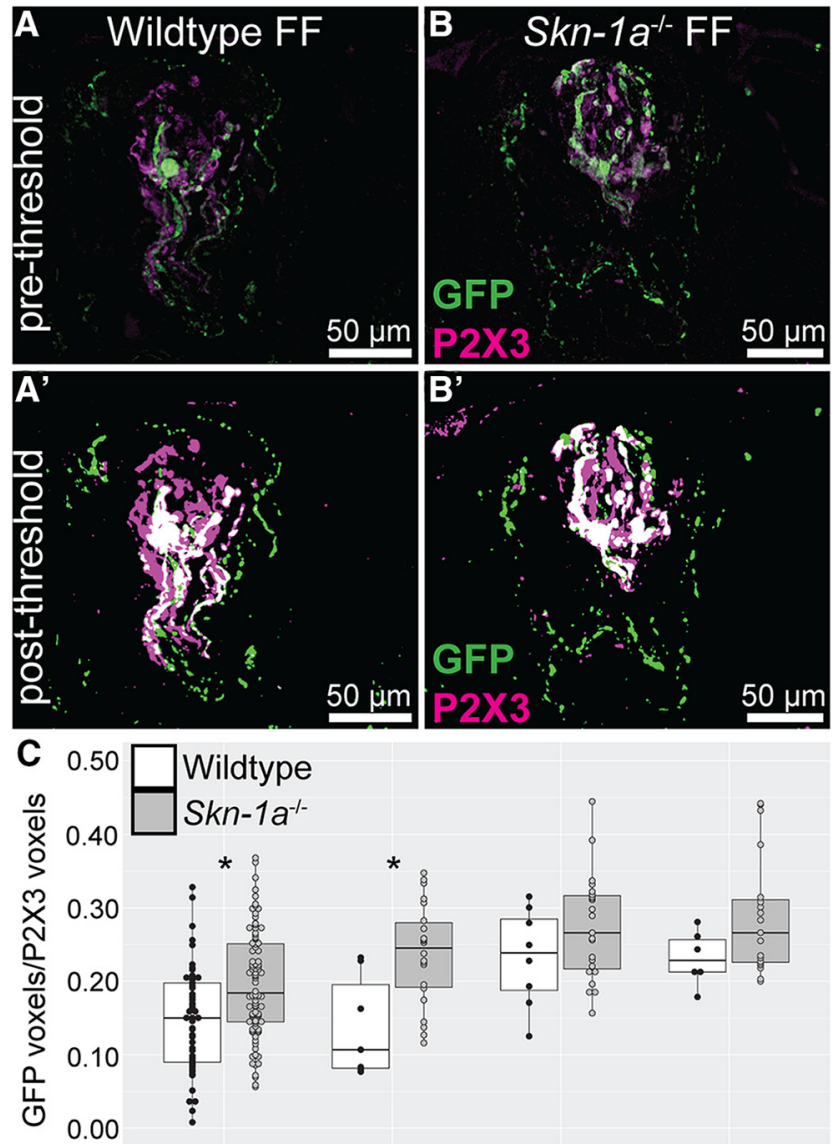
Wildtype Skn-1 $a^{-1-}$

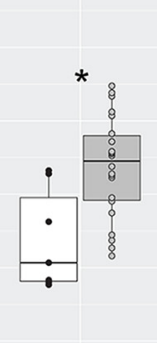

Fol

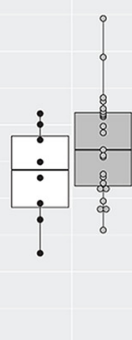

FF

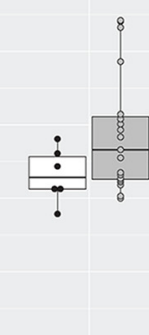

SP
Figure 7. $5-\mathrm{HT}_{3 \mathrm{~A}^{-}} \mathrm{GFP}$ innervation in $S k n-1 a^{-/-}$mice. $5-\mathrm{HT}_{3 A^{-}}$ GFP mice were crossed with $S k n-1 a^{-/-} . S k n-1 a^{-/-}$mice that had the GFP transgene and WT littermates that also had the GFP transgene were used for experiments. $\boldsymbol{A}, \boldsymbol{B}$, Maximal z-projections of fungiform taste buds from WT and KO mice labeled with antibodies against GFP (green) and P2X3 (magenta). A', B', Same image as $\boldsymbol{A}, \boldsymbol{B}$ but after prepressing which included Otsu thresholding. $\boldsymbol{C}$, Analysis was performed on each optical plan of individual taste buds to quantify the relative immunoreactivity of P2X3 and GFP; $* p<0.05$ by Kruskal-Wallis test followed by Dunn test for multiple comparisons. Three to four mice from each genotype were used, and 228 taste buds were quantified.

which show a significant amiloride-insensitive response in mice lacking Type II taste cells. The amiloride-sensitive salt taste is believed to be transduced by a cell Type Independent of Type II and Type III cells in mice (Vandenbeuch et al., 2008; Chandrashekar et al., 2010), although whether it is a unique cell type or a subset of Type I cells is still unclear.

PKD1L3 is expressed in Type III cells of posterior tongue, and transgenic mice expressing WGA from the $P k d 1 / 3$ promoter show WGA in Type III cells of circumvallate and foliate papillae as well as in petrosal ganglion neurons (Yamamoto et al., 2011). Maeda et al. (2017) crossed these PKD1L3-WGA expressing mice into the $S k n-1 a^{-/-}$mice and examined the circumvallate taste buds and petrosal ganglion neurons for evidence of WGA protein. WGA protein was much higher in the taste buds of the KO mice than WT, but the number of ganglion cells

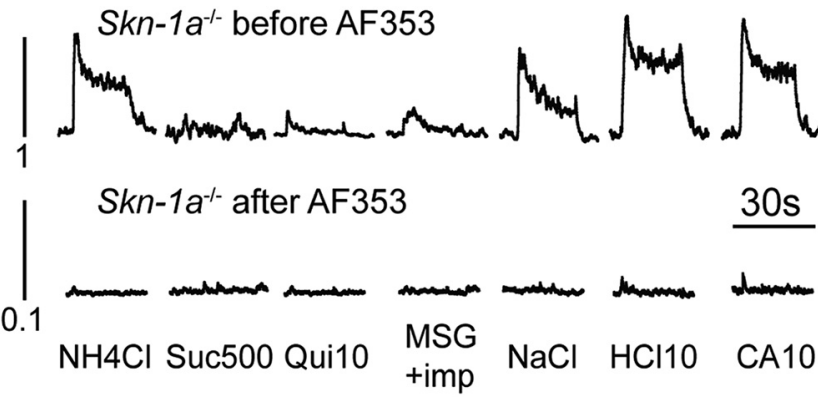

Figure 8. Purinergic receptor antagonism eliminates residual chorda tympani responses to lingually applied taste solutions. The chorda tympani response to taste solutions was measured in $S k n-1 a^{-/-}$before and after application of $1 \mathrm{mM} \mathrm{AF353.} \mathrm{Data}$ are representative integrated responses to each stimulus. The $y$-axis scale is an order of magnitude smaller on the responses after AF353. Responses are representative of four animals.

containing WGA was not different from control mice, leading them to conclude that ganglion cell innervation is not regulated by taste cell type. We have expanded on this observation to examine the geniculate ganglion using mice expressing GFP from the serotonin receptor $\mathrm{Htr} 3 \mathrm{a}$ promoter. Geniculate neurons expressing $5-\mathrm{HT}_{3 \mathrm{~A}}$-GFP preferentially innervate the serotonergic Type III taste cells and these neurons respond to both 5-HT and ATP, while neurons lacking GFP expression respond only to ATP (Larson et al., 2015; Stratford et al., 2017). A recent study confirms that most $5-\mathrm{HT}_{3 \mathrm{~A}}$ fibers innervate Type III cells. Secondary analysis of single cell RNA-sequencing data shows that geniculate ganglion neurons that respond to sour lingual stimuli are enriched with $\mathrm{Htr} 3 \mathrm{a}\left(5-\mathrm{HT}_{3 \mathrm{~A}}\right.$; data not shown; Dvoryanchikov et al., 2017; Zhang et al., 2019). We crossed the 5-HT $3 \mathrm{~A}^{-\mathrm{GFP}}$ mice into the Skn$1 a^{-/-}$mice and asked whether the ratio of GFP expressing neurons differed between KO and WT mice. Our results

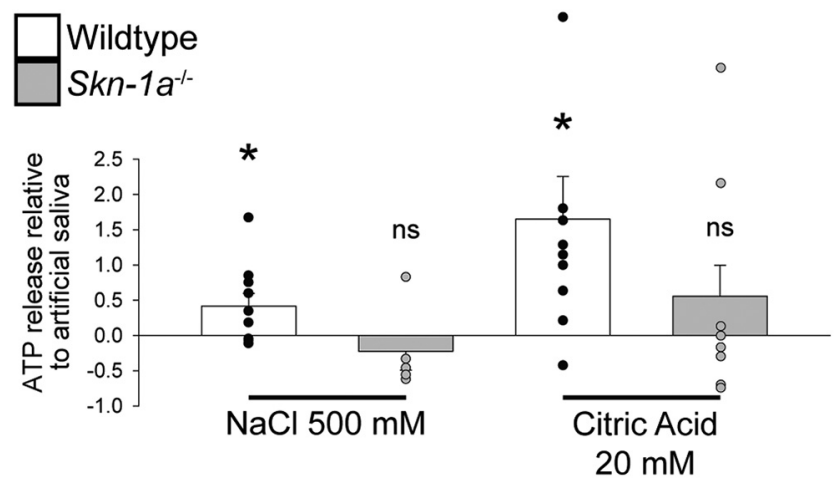

Figure 9. No detectable ATP release from taste buds of Skn$1 a^{-/-}$mice. ATP release was measured from peeled circumvallate epithelium of $\mathrm{Skn}^{-1 \mathrm{a}^{-/-}}$and WT littermates via luciferase assay. Stimuli were $500 \mathrm{mM} \mathrm{NaCl}, 20 \mathrm{mM}$ citric acid, and artificial saliva. Data are presented relative to artificial saliva. Bar charts indicate sample mean relative to artificial saliva, error bars represent SEM, and superimposed dot plot represents each individual trial; $* p<0.05$ compared with artificial saliva; ns $=$ not significant compared with artificial saliva; $N=14$ WT and $N=8 \mathrm{Skn}-1 \mathrm{a}^{-/-}$mice. 
suggest that while the Type III taste cells of the $\mathrm{KO}$ are expanded, the 5- $\mathrm{HT}_{3 \mathrm{~A}}$ expressing ganglion cells do not undergo a similar expansion, in general agreement with Maeda et al. (2017). Further, we showed that only the GFP-labeled ganglion neurons responded to exogenous $5-\mathrm{HT}$, while the majority of neurons responded to ATP, as with the WT animals. These results beg the question of whether the "extra" Type III cells in the KO mice are actually innervated. To assess this, we compared the innervation density of P2X3-expressing nerve fibers surrounding taste buds of circumvallate, foliate, fungiform, and palatal taste buds in KO and WT mice. All gustatory geniculate ganglion neurons express P2X3 (Bo et al., 1999; Ishida et al., 2009; Dvoryanchikov et al., 2017) and thus P2X3 is a reliable marker for taste bud innervation density. However, we found no difference in the overall innervation density between taste buds of the $\mathrm{KO}$ and WT mice, suggesting that all taste cells are likely to be innervated. It still remains possible that either $5-\mathrm{HT}_{3 \mathrm{~A}}-\mathrm{ex}-$ pressing ganglion neurons have increased nerve fiber branching to innervate the expanded population of Type III cells in the $\mathrm{KO}$, or the ganglion neurons expressing only P2X3 are now innervating the Type III cells. To address this, we quantified the proportion of P2X3-immunoreactive nerve fibers that were also $5-\mathrm{HT}_{3 \mathrm{~A}}-\mathrm{GFP}+$ in $\mathrm{Skn}-1 \mathrm{a}^{-/-}$ and Skn-1aWT mice crossed with 5HT3A-GFP mice (Fig. 7). We observed slight increases in the proportion of GFP + gustatory fibers, although significance was only reached in the circumvallate and foliate papillae. This suggests that increased branching of GFP+ fibers could be occurring $S k n-1 a^{-/-}$mice. This would be consistent with observations that chorda tympani response to sour and salty stimuli are not increased, as one would expect much larger nerve signals if more neurons are being recruited from the increased number of Type III cells. However, further studies will be required to explore this question in more detail with enhanced resolution.

Previous studies have shown that ATP is required for the transmission of all taste qualities (Finger et al., 2005; Vandenbeuch et al., 2015), although only Type II cells are known to release ATP (Huang et al., 2007; Romanov et al., 2007, 2018; Taruno et al., 2013). The source of ATP required for transmission from Type III cells to gustatory afferents has remained an enigma, although it has been assumed to require the presence of Type II cells. Thus, it was of interest to examine the role of ATP in Skn-1 $a^{-1 /}$ mice which lack Type II cells. Using a luciferin/luciferase assay, we found that taste buds of WT mice release detectible amounts of ATP to sour and salty stimuli applied to the apical membrane, but the Skn-1a $a^{-/-}$mice failed to release ATP over background levels in the tissue. The finding that ATP release, presumably from Type II cells, is elicited by sour and salty was surprising and consistent with a model where signaling between taste receptor cells occurs (Huang et al., 2009). In this situation, activation of Type III cells by sour or salty stimuli causes indirect activation of Type II cells to release ATP. ATP release to sour and salty stimuli is specific to Type II cells as it is absent in Skn-1 $1 a^{-/-}$mice.

We found that the purinergic receptor antagonist AF353 blocked transmission of sour and salty tastes in the $\mathrm{KO}$ as well as in the WT littermates. Thus, purinergic signaling is still required in these mice that lack Type II taste cells. But what is the source of the ATP, if not Type II cells? Our best explanation is that small amounts of ATP may be released from Type III cells that are undetectable by our assay and others' attempts to measure ATP release from Type III cells (Huang et al., 2007; Romanov et al., 2007). One possibility is that ATP is co-released with serotonin (or other transmitters) from synaptic vesicles, thus it may be very focal and difficult to detect in this type of assay. Indeed, ATP is very commonly co-packaged in synaptic vesicles and often co-released with transmitters such as norepinephrine and acetylcholine [as reviewed in Borges (2013) and Burnstock (2006)]. Additionally, analysis of data from Qin et al., 2018 shows that using single cell RNA-sequencing Slc17a9 (VNUT) is detectable in both Type II and III cells. While Iwatsuki et al. (2009) showed immunoreactivity to VNUT only in Type II cells the discrepancy could arise from the sensitivity of the assays used. These findings support the hypothesis that ATP could be released from vesicles of Type III cells at low levels sufficient for synaptic communication but insufficient for detection by conventional methods.

We also propose that pannexin channels could be a source of ATP release from Type III cells. While KO of pannexin-1 shows no phenotype, it is possible that in the absence of Type II cells and CALHM1 channels, pannexin-1 could take over a role for ATP release. Indeed, analysis of single cell RNA-sequencing data from Qin et al. (2018) shows detectable levels of Panx 1 in the majority of Type III cells (data not shown). A final possibility is that background levels of ATP in the tissues serve to keep gustatory afferents in a slightly depolarized state, so that release of serotonin or other transmitters will be sufficient to generate action potentials in the ganglion cells. Further studies will be required to resolve this issue.

\section{References}

Andersen B, Weinberg WC, Rennekampff O, McEvilly RJ, Bermingham JR, Hooshmand F, Vasilyev V, Hansbrough JF, Pittelkow MR, Yuspa SH, Rosenfeld MG (1997) Functions of the POU domain genes Skn-1a/i and Tst-1/Oct-6/SCIP in epidermal differentiation. Genes Dev 11:1873-1884.

Bivand RS, Pebesma E, Gomez-Rubio V (2013) Applied spatial data analysis with R, Ed 2. New York: Springer.

Bivand R, Keitt T, Rowlingson B (2019) rgdal: Bindings for the "geospatial" data abstraction library. Available at https://CRAN.Rproject.org/package=rgdal version 1.4-8.

Bo X, Alavi A, Xiang Z, Oglesby I, Ford A, Burnstock G (1999) Localization of ATP-gated P2X2 and P2X3 receptor immunoreactive nerves in rat taste buds. Neuroreport 10:1107-1111.

Borges R (2013) The ATP or the natural history of neurotransmission. Purinergic Signal 9:5-6.

Burnstock G (2006) Historical review: ATP as a neurotransmitter. Trends Pharmacol Sci 27:166-176.

Bushman JD, Ye W, Liman ER (2015) A proton current associated with sour taste: distribution and functional properties. FASEB $J$ 29:3014-3026.

Chandrashekar J, Kuhn C, Oka Y, Yarmolinsky DA, Hummler E, Ryba NJP, Zuker CS (2010) The cells and peripheral representation of sodium taste in mice. Nature 464:297-301. 
Cronan MR, Rosenberg AF, Oehlers SH, Saelens JW, Sisk DM, Smith KLJ, Lee S, Tobin DM (2015) CLARITY and PACT-based imaging of adult zebrafish and mouse for whole-animal analysis of infections. Dis Med Mech 8:1643-1650.

Dinno A (2017) dunn.test: Dunn's test of multiple comparisons using rank sums. Available at https://CRAN.R-project.org/package= dunn.test version 1.3.5.

Dvoryanchikov G, Hernandez D, Roebber JK, Hill DL, Roper SD, Chaudhari N (2017) Transcriptomes and neurotransmitter profiles of classes of gustatory and somatosensory neurons in the geniculate ganglion. Nat Commun 8:760.

Finger TE, Danilova V, Barrows J, Bartel DL, Vigers AJ, Stone L, Hellekant G, Kinnamon SC (2005) ATP signaling is crucial for communication from taste buds to gustatory nerves. Science 310:1495-1499.

Hijmans RJ (2019) raster: Geographic data analysis and modeling. Available at https://CRAN.R-project.org/package=raster version 3.0-7.

Huang YA, Maruyama Y, Stimac R, Roper SD (2008) Presynaptic (type III) cells in mouse taste buds sense sour (acid) taste. J Physiol 586:2903-2912.

Huang YA, Dando R, Roper SD (2009) Autocrine and paracrine roles for ATP and serotonin in mouse taste buds. J Neurosci 29:1390913918.

Huang YA, Pereira E, Roper SD (2011) Acid stimulation (sour taste) elicits GABA and serotonin release from mouse taste cells. PLoS One 6:e25471.

Huang YJ, Maruyama Y, Dvoryanchikov G, Pereira E, Chaudhari N, Roper SD (2007) The role of pannexin 1 hemichannels in ATP release and cell-cell communication in mouse taste buds. Proc Natl Acad Sci USA 104:6436-6441.

Ishida $Y$, Ugawa S, Ueda T, Yamada T, Shibata $Y$, Hondoh A, Inoue $\mathrm{K}, \mathrm{Yu}$ Y, Shimada S (2009) P2X2- and P2X3-positive fibers in fungiform papillae originate from the chorda tympani but not the trigeminal nerve in rats and mice. J Comp Neurol 514:131-144.

Iwatsuki K, Ichikawa R, Hiasa M, Moriyama Y, Torii K, Uneyama H (2009) Identification of the vesicular nucleotide transporter (VNUT) in taste cells. Biochem Biophys Res Commun 388:1-5.

Kretz O, Barbry P, Bock R, Lindemann B (1999) Differential expression of RNA and protein of the three pore-forming subunits of the amiloride-sensitive epithelial sodium channel in taste buds of the rat. J Histochem Cytochem 47:51-64.

Larson ED, Vandenbeuch A, Voigt A, Meyerhof W, Kinnamon SC, Finger TE (2015) The role of 5-HT3 receptors in signaling from taste buds to nerves. J Neurosci 35:15984-15995.

Lewandowski BC, Sukumaran SK, Margolskee RF, Bachmanov AA (2016) Amiloride-insensitive salt taste is mediated by two populations of type III taste cells with distinct transduction mechanisms. J Neurosci 36:1942-1953.

Maeda N, Narukawa M, Ishimaru Y, Yamamoto K, Misaka T, Abe K (2017) A large increase of sour taste receptor cells in Skn-1-deficient mice does not alter the number of their sour taste signaltransmitting gustatory neurons. Neurosci Lett 648:53-58.

Matsumoto I, Ohmoto M, Narukawa M, Yoshihara Y, Abe K (2011) Skn-1a (Pou2f3) specifies taste receptor cell lineage. Nat Neurosci 14:685-687.

Murata Y, Yasuo T, Yoshida R, Obata K, Yanagawa Y, Margolskee RF, Ninomiya Y (2010) Action potential-enhanced ATP release from taste cells through hemichannels. J Neurophysiol 104:896901.
Ogle DH, Wheeler P, Dinno A (2019) FSA: Fisheries stock analysis. Available at https://github.com/droglenc/FSA version 0.8.26.

Oka Y, Butnaru M, von Buchholtz L, Ryba NJP, Zuker CS (2013) High salt recruits aversive taste pathways. Nature 494:472-475.

Pebesma EJ, Bivand RS (2005) Classes and methods for spatial data in R. R News 5:9-13.

Qin Y, Sukumaran SK, Jyotaki M, Redding K, Jiang P, Margolskee RF (2018) Gli3 is a negative regulator of Tas1r3-expressing taste cells. PLoS Genet 14:e1007058.

Roebber JK, Roper SD, Chaudhari N (2019) The role of the anion in salt (NaCl) detection by mouse taste buds. J Neurosci 39:62246232.

Romanov RA, Rogachevskaja OA, Bystrova MF, Jiang P, Margolskee RF, Kolesnikov SS (2007) Afferent neurotransmission mediated by hemichannels in mammalian taste cells. EMBO J 26:657667.

Romanov RA, Lasher RS, High B, Savidge LE, Lawson A, Rogachevskaja OA, Zhao H, Rogachevsky VV, Bystrova MF, Churbanov GD, Adameyko I, Harkany T, Yang R, Kidd GJ, Marambaud P, Kinnamon JC, Kolesnikov SS, Finger TE (2018) Chemical synapses without synaptic vesicles: Purinergic neurotransmission through a CALHM1 channel-mitochondrial signaling complex. Sci Signal 11:eaao1815.

Roper SD, Chaudhari N (2017) Taste buds: Cells, signals and synapses. Nat Rev Neurosci 18:485-497.

Stratford J, Larson E, Yang R, Salcedo E, Finger T (2017) $5-\mathrm{HT}_{3 \mathrm{~A}^{-}}$ driven green fluorescent protein delineates gustatory fibers innervating sour-responsive taste cells: A labeled line for sour taste? J Comp Neurol 525:2358-2375.

Taruno A, Vingtdeux V, Ohmoto M, Ma Z, Dvoryanchikov G, Li A, Adrien L, Zhao H, Leung S, Abernethy M, Koppel J, Davies P, Civan MM, Chaudhari N, Matsumoto I, Hellekant G, Tordoff MG, Marambaud P, Foskett JK (2013) CALHM1 ion channel mediates purinergic neurotransmission of sweet, bitter and umami tastes. Nature 495:223-226.

Vandenbeuch A, Clapp TR, Kinnamon SC (2008) Amiloride-sensitive channels in type I fungiform taste cells in mouse. BMC Neurosci 9:1.

Vandenbeuch A, Anderson CB, Parnes J, Enjyoji K, Robson SC, Finger TE, Kinnamon SC (2013) Role of the ectonucleotidase NTPDase2 in taste bud function. Proc Natl Acad Sci USA 110:14789-14794.

Vandenbeuch A, Larson ED, Anderson CB, Smith SA, Ford AP, Finger TE, Kinnamon SC (2015) Postsynaptic P2X3-containing receptors in gustatory nerve fibres mediate responses to all taste qualities in mice. J Physiol 593:1113-1125.

Wilson CE, Finger TE, Kinnamon SC (2017) Type III cells in anterior taste fields are more immunohistochemically diverse than those of posterior taste fields in mice. Chem Senses 42:759-767.

Yamamoto K, Ishimaru Y, Ohmoto M, Matsumoto I, Asakura T, Abe K (2011) Genetic tracing of the gustatory neural pathway originating from Pkd1/3-expressing type III taste cells in circumvallate and foliate papillae. J Neurochem 119:497-506.

Ye W, Chang RB, Bushman JD, Tu Y-H, Mulhall EM, Wilson CE, Cooper AJ, Chick WS, Hill-Eubanks DC, Nelson MT, Kinnamon SC, Liman ER (2016) The K+ channel KIR2.1 functions in tandem with proton influx to mediate sour taste transduction. Proc Natl Acad Sci USA 113:ECCXXIX-ECCXXXVIII.

Zhang J, Jin H, Zhang W, Ding C, O'Keeffe S, Ye M, Zuker CS (2019) Sour sensing from the tongue to the brain. Cell 179:392-402.e15. 